\title{
The Limits of Inequality: Public Support for Social Policy across Rich Democracies
}

\author{
Nate Breznau $^{1}$, Carola Hommerich ${ }^{2}$ \\ ${ }^{1}$ Mannheim Centre for European Social Research (MZES), Mannheim, Germany \\ ${ }^{2}$ Hokkaido University, Graduate School of Letters, Sapporo, Japan
}

\begin{abstract}
Does public opinion react to inequality, and if so, how? The social harms caused by increasing inequality should cause public opinion to ramp up demand for social welfare protections. However, the public may react to inequality differently depending on institutional context. Using ISSP and WID data (1980-2006) we tested these claims. In liberal institutional contexts (mostly English-speaking), increasing income inequality predicted higher support for state provision of social welfare. In coordinated and universalist contexts (mostly of Europe), increasing inequality predicted less support. Historically higher income concentration predicted less public support, providing an account of the large variation in inequality within the respective liberal and coordinated contexts. The results suggest opinions in liberal societies especially with higher historical inequality - reached the limits of inequality, reacting negatively; whereas in coordinated/universalist societies - especially with lower historical inequality - opinions moved positively, as if desiring more inequality.
\end{abstract}

Key words: Income inequality, public opinion, social welfare policy, liberalisation, welfare state 
The post-war 'Golden Age' of welfare states led to unprecedented levels of socio-economic equality among most rich democracies (Esping-Andersen, 1996; Wilensky, 1975). However, this trend has reversed since the 1970s (OECD, 2008; Piketty, 2014). Although globalisation and financialisation are partly to blame, retrenchments in various social welfare state policies are also a cause (Hall \& Thelen, 2009; Pierson, 2002; Roberts \& Saeed, 2012). Governments have reduced public services, employment protection, education and pensions (DiPrete \& Eirich, 2006; Kwon, 2016; Leibfried \& Mau, 2008; Lewis, 2001; Obinger, Schmitt, \& Zohlnhöfer, 2014), which has resulted in wealth inequality, health inequality and poverty increases (Beckfield et al., 2015; Pickett \& Wilkinson, 2015). There is evidence that income inequality stunts economic growth above certain thresholds (Krueger, 2012), reversing the traditionally understood efficiency-equality trade-off (Okun, 1975). An explanation of these trends under functional democratic institutions is that the public supported them. Over time, public opinions should favour a greater state role in counteracting inequality's destructive outcomes (Therborn, 2013). This is particularly true of greater income concentration in the top $1 \%$ as this goes hand-in-hand with increasing poverty across rich democratic societies (Atkinson, 2015). As historical levels of inequality and the institutions of the social welfare state differ markedly across societies, it is likely that the opinion-policy linkage also differs by context.

\section{Public reactions to income inequality}

Looking at the net increases in income inequality measured as income concentration at the top provides a simple glimpse into the complex evolution of myriad social inequalities among rich democracies. Figure 1 shows income inequality as the share of all national income in the hands of the top $10 \%$ of the income distribution in each society. The light part of each bar is the top $10 \%$ share in 1980 , while the dark coloured bar represents the expansion of this overall share up to $2006 .^{1}$

\footnotetext{
${ }^{1}$ We refer to the 13 societies in Figure 1 as 'countries' for ease of discussion. Our sample of rich countries is by no means exhaustive. It consists of those for which we have relevant measures. Nonetheless, it offers cases from the major institutional dichotomy - liberal and coordinated. This excludes sub dichotomies, for example the Mediterranean regime type.
} 
Figure 1. Top 10\% share of national income, 1980 and 2006.

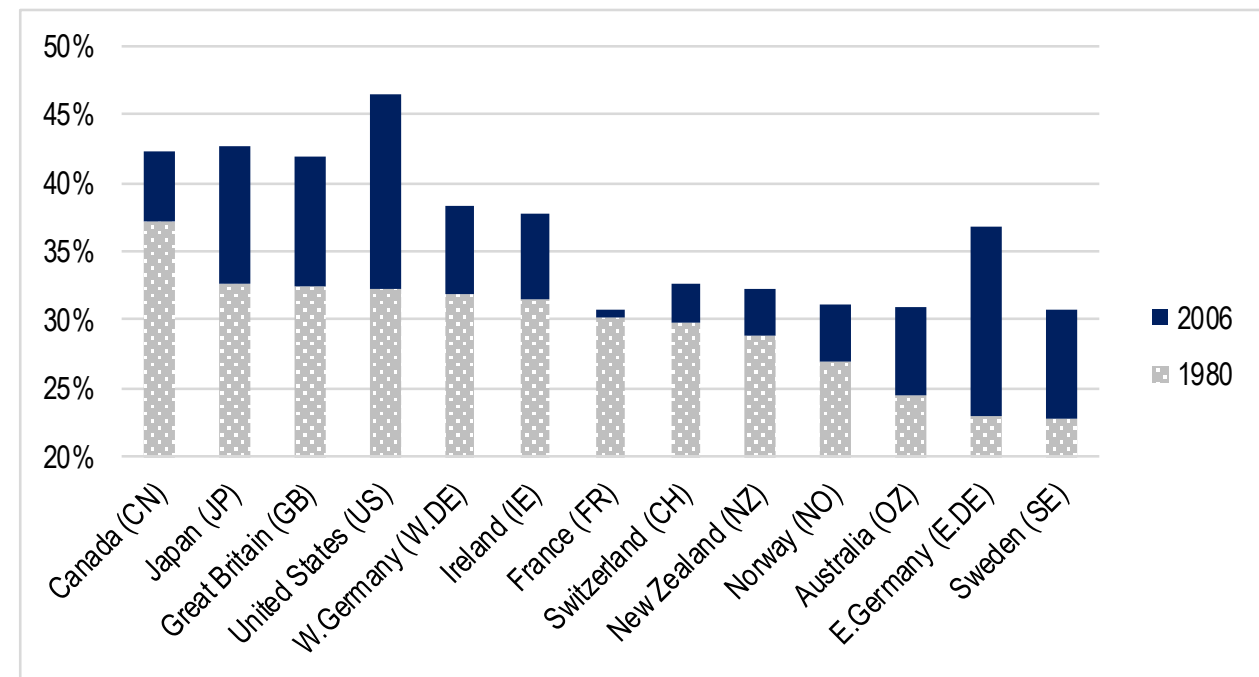

Source: World Inequality Database (WID, 2017). Bars not stacked; dark portion represents growth in inequality since 1980 .

A general theory of democratic institutions predicts that policymakers respond to public preferences, and public opinion research generally supports this proposition (Burstein, 1998; Soroka \& Wlezien, 2010). If true, then support for social welfare must fall in order for income inequality to climb, and vice-versa (Weakliem, Andersen, \& Heath, 2005). Yet the public should support increases to protective social policies because increasing inequality harms them (Hansung et al., 2017), not to mention that majorities benefit from most redistributive social policies.

Nonetheless, the public may form opinions against their material interests (Linos \& West, 2003). Although the state is the only mechanism that can legally institutionalise equality for an entire society (Brady, 2009), the public may lose confidence in competence or effectiveness of the state in providing social welfare (Bartels, 1986; Bendz, 2015; Patashnik \& Zelizer, 2013; Pierson, 1996; Soss \& Schram, 2007). Moreover, increasing power among the richest members of society allow them to persuade the public to adopt 'rich-like' policy preferences (Bourdieu, 1984; Habermas 1989; Lupu \& Pontusson, 2011), or convince them to oppose social welfare because immigrants abuse it (Breznau \& Eger, 2016; Gilens, 2009). Thus, various arguments point toward a link between increasing inequality and lower support for 
social welfare, even if this may harm a public majority. Given that we observe increasing inequality among rich democracies, one simply hypothesis is that this results from public preferences. We refer to attitudes in favour of state intervention into the economy, with the intention of protecting public welfare or redistributing resources, as public support for social welfare. Thus: (H1) Public support for social welfare decreases inversely with income inequality increases.

Aggregate measures of inequality reflect individual struggles to meet basic needs (Atkinson, 2015). At some point, the extremity of these struggles should trump arguments supporting H1, leading to shifts in mass opinion in favour of social welfare. However, institutional theory predicts that inequality and public opinion are context-specific to some degree suggesting that their relationship is not as simple as $\mathrm{H} 1$ or its converse.

Individuals in historically more unequal societies are used to a higher degree of top income concentration, thus increases in this concentration may simply provide more of what the public already knows if not wants; an argument of path dependency (Kelly \& Enns, 2010; Mau, 2004; Wegener \& Liebig, 1995). However, there are theoretical limits of inequality where the harm outweighs institutionalised norms. Certainly many bloody revolutions in history came at the hands of extreme inequality (French, Bolshevik, etc.). On the other hand, in historically more equal contexts, publics might reach the theoretical limits of equality and instead seek to bring more neo-liberal market-orientations into their society.

Varieties of capitalism (Hall and Soskice 2001), cultural institutions (Arts \& Gelissen, 2001; Castles, 1993; Orloff \& Skocpol, 1984) and welfare state regimes (Esping-Andersen, 1989) provide theoretically alternative typologies of societies that are empirically similar (see discussion in Breznau, 2015). In particular, the distinction between liberal welfare state capitalist institutions and coordinated (more social democratic) welfare states is of major analytical importance. These are somewhat polarised institutional contexts in terms of how governments function and intervene in socio-economic affairs. 
Although liberal societies (mostly English-speaking) tend to be more unequal than coordinated or social democratic ones (mostly European and Japan), Figure 1 demonstrates that there is also variation within each type. Institutional theory suggests that path dependency shapes public preferences; however, this refers to both institutions (as in laws, political processes and the welfare state) and normative orientations (principles of competition and inequality versus cooperation, for example inequality of opportunity versus outcomes) (Pierson, 2000). Therefore, we target both as, (a) the historical level of inequality, and (b) the degree of institutionalised redistribution (i.e., welfare state). We argue that: (H2) Societies with higher historical levels of income inequality and/or liberal institutional contexts have lower support for social welfare on average, but (H3) have higher support for social welfare as a function of increases in income inequality.

H3 could read that more social-statist European societies show less increase or possibly decrease in support for social welfare because they are far away from the limits of inequality.

\section{Empirical design}

To test our hypotheses, we used comparative survey data from the 13 countries shown in Figure 1. We used multilevel regression modelling allowing us to parse out a great deal of unobserved homogeneity within, and heterogeneity between countries and country-time points. Although our strategies point toward causality, we assume there are shared confounding if not reciprocal causes of liberalisation, income inequality and support for social welfare, meaning we speculate on causal relationships rather than empirically confirm them in this research. Following best practices of the open science movement, we publish all of our code and technical specs online ${ }^{2}$.

\footnotetext{
${ }^{2}$ https://osf.io/m3zwv/
} 


\section{Measurement}

The International Social Survey Program (ISSP) 'Role of Government' modules I-IVª fielded between 1985 and 2006 are uniquely appropriate data. Others start much later (e.g. European Social Survey), have few countries (e.g. International Survey of Economic Attitudes), or do not ask social welfare questions (e.g. World Values Surveys).

We measured our dependent variable public Support for social welfare with predictive common factor scoring from five questions regarding the responsibility of government to provide jobs, price controls, health care, old-age living standards and unemployment subsidies. Answers coded on a four-point scale from 'definitely should be' to 'definitely should not be' (see Table A1 and the Addendum in the Appendix). These questions are a mainstay of social welfare attitude research (Bean \& Papadakis, 1998; Jæger, 2009; Svallfors, 1997).

We measured time as a yearly counter starting with zero for the earliest observation within each country, labelled Year $^{4}$, and then mean-centred it by country. This captures changes over time within countries on average, as opposed to global period effects. We measured withincountry change in income inequality (Inequality growth) as the ratio of the current share of all income in the hands of the top $10 \%$ of the net taxable income distribution split by couples, to that in 1980 using data from the World Inequality Database (WID 2017); for example, the top $10 \%$ concentration in Sweden changed from $23 \%$ in 1980 to $31 \%$ in 2006 for a ratio of $(31 / 23=) 1.35$ (see Figure 1). We measured historical inequality as the top $1 \%$ income concentration in 1980 (Inequality_1980). We measured institutions by dividing the countries into a group of liberal, mostly English-speaking (Liberal=1) versus social/coordinated, mostly European $(=0)$. We added Japan to the European group because of coordination and civil as opposed to common law (see Table 1 for coding) (Hall \& Soskice, 2001; Weakliem, 2016).

\footnotetext{
${ }^{3}$ Data downloaded from GESIS https://www.gesis.org/issp/home/. Countries that include data on all relevant variables listed in Table 1 with Germany are split into former East and West.

${ }^{4}$ For example, in Great Britain 1986=zero, 1990=four, 1996=10 and 2006=20
} 
Independent variables from welfare state and policy attitude research helped us adjust aggregate opinion to be comparable across societies as means of controlling composition effects, i.e., 'all else equal' (Eger \& Breznau, 2017; Sundberg \& Taylor-Gooby, 2013; Svallfors, 1997). These include Age in years, Aged over 64 or not, Female, Full-time employed, Education in years and Occupational status ISEI (Ganzeboom, De Graaf, \& Treiman, 1992) and Union membership. These variables helped us account for somewhat different sampling techniques across the ISSP. Table 1 presents descriptive statistics. 
Table 1. Descriptive statistics for variables at three levels.

\begin{tabular}{|c|c|c|c|c|c|}
\hline Individual-level $(N=37,442)$ & Measure & Mean & S.d. & Min. & Max. \\
\hline Support & $\begin{array}{l}\text { Dependent variable measuring public } \\
\text { support for social welfare as latent, } \\
\text { see Addendum }\end{array}$ & 0 & 0.822 & -4.39 & 1.67 \\
\hline Age & in years & 45.44 & 16.17 & 18 & 87 \\
\hline Aged & over age $64=1$ & 0.16 & 0.37 & 0 & 1 \\
\hline Female & female $=1$ & 0.50 & 0.50 & 0 & 1 \\
\hline Full & full-time employment=1 & 0.51 & 0.50 & 0 & 1 \\
\hline Education & in years & 11.96 & 3.41 & 0 & 21 \\
\hline ISEI & see text & 45.40 & 14.52 & 16 & 90 \\
\hline Union & member $=1$ & 0.25 & 0.43 & 0 & 1 \\
\hline Country-time-level $(N=36)^{\mathrm{a}}$ & Measure & Mean & S.d. & Min. & Max. \\
\hline Support & $\begin{array}{l}\text { Latent, composition-corrected, } \\
\text { country mean centred }\end{array}$ & -0.01 & 0.12 & -0.29 & 0.22 \\
\hline Year $^{\mathrm{b}}$ & $\begin{array}{l}\text { Yearly counter; } 0=\text { first survey year } \\
\text { within countries }\end{array}$ & 15.83 & 8.26 & 0 & 26 \\
\hline Inequality_growth & $\begin{array}{l}\text { Ratio of current top } 10 \% \text { income } \\
\text { share to } 1980\end{array}$ & 1.15 & 0.13 & 0.97 & 1.60 \\
\hline Inequality_1980 & Top 1\% income share in 1980 & 0.07 & 0.02 & 0.04 & 0.11 \\
\hline Liberal $^{c}$ & $\begin{array}{l}\text { Liberal, unequal }=1 ; \\
\text { social, statist } / \text { more equal }=0\end{array}$ & 0.50 & 0.51 & 0 & 1 \\
\hline Liberal*Inequality_growth & & 0.58 & 0.59 & 0 & 1.44 \\
\hline $\begin{array}{l}\text { Inequality_1980* } \\
\text { Inequality_growth }\end{array}$ & Interactions & 0.08 & 0.03 & 0.04 & 0.14 \\
\hline Country-level $(N=13)$ & Measure & Mean & S.d. & Min. & Max. \\
\hline Support & Latent, composition-corrected & 0.37 & 0.32 & -0.10 & 0.91 \\
\hline Inequality_1980 & Top $1 \%$ income share in 1980 & 0.07 & 0.02 & 0.04 & 0.11 \\
\hline Liberal $^{\mathrm{c}}$ & $\begin{array}{l}\text { Liberal, unequal }=1 ; \\
\text { social, statist } / \text { more equal }=0\end{array}$ & 0.46 & 0.52 & 0 & 1 \\
\hline Liberal*Inequality_growth & & 0.53 & 0.60 & 0 & 2.00 \\
\hline $\begin{array}{l}\text { Inequality_1980* } \\
\text { Inequality_growth }\end{array}$ & Interactions & 0.08 & 0.02 & 0.05 & 0.12 \\
\hline
\end{tabular}

\footnotetext{
${ }^{a}$ Year and Inequality_growth are country-mean centred in analysis but reported uncentred here. Variables at the individual level used only in the initial models to remove individual-level variance and composition effects, then main models estimated as two-level models (see text for explanation).

${ }^{\mathrm{b}}$ Average observations per second-level unit are 2.77 (OZ 3, CN 2, FR 2, W.DE 4, E.DE 3, IE 3, JP 2, NZ 2, NO

3, SE 2, CH 2, GB 4, US 4).

${ }^{\mathrm{c}}$ Liberal are OZ, CN, IE, NZ, GB and US and social are JP, FR, W.\&E.DE, NO, SE and CH.
} 


\section{Modelling}

Our model has nesting of individuals ('level-0') in country-years (level-1) in countries (level2); however, our interest is only on public opinion. Thus, we adjusted our level-1 measures to correct for composition effects from 'level-0' (using MA and MB in Table 2) and then from M0 onward we used only country-time (level-1) and country (level-2), as two-level models (see Hox, 2010).

These countries are not a random sample of a 'population'. Using all possible cases, we have 36 time points in 13 countries making tests of coefficient significance dubious. The data generating 'population' if it in fact existed would be rich democracies. The null hypothesis would then suggest that significant coefficients are not likely given the read-world as reflected in our random-sample. We have no distributional basis to test this null, we simply have the rich countries selected (not sampled) in the ISSP. Rather than testing the null hypothesis regarding our coefficients, our focus is on likelihood-ratio tests using the chi-square p-value. These allow us to conclude whether each hypothesised model fit the observed data better or worse than the null, or better or worse than other hypothesised models. This is an exercise in theory building and testing (Hayduk et al., 2007) rather than the likelihood of a parameter in the real-world population. Additionally, we relied on Akaike's Information Criteria (AIC) and reductions in residual variance for further testing. This model testing and comparing gives a qualitative interpretability to the mathematically derived observations of these societies and their opinion and inequality linkages. A significant chi-square $p$-value $(\mathrm{p}<.05)$ suggests significantly worse fit than the null model (M0). Smaller AIC suggests better fit in general (Chen et al., 2008), as do reductions in explained variance.

First, we tested H1's prediction of a time trend in Support by modelling a fixedcoefficient (random-effect) for Year, centred within countries (M1). Then we added randomslopes ('fixed-effects' modelling) for Year (M2), and likewise for Inequality_growth (M3 and M4). Then we combined Year and Inequality_growth (M5), and then added Inequality_1980 
(M6). We added M4-M6 as a-theoretical models designed only to fit random-slopes to explain the maximum amount of variance possible. They set a baseline for comparison of our theoretically derived models. M7 and M8 test H2 adding Inequality_1980 then exchanging it for Liberal. We expect changes in income inequality depend on the type of society in $\mathrm{H} 3$ and thus interacted Inequality_1980 at level-3 with Inequality_growth at level-2 in M9, and then swapped Inequality_1980 for Liberal in M10-M12. Next, M11 included Inequality_1980 as the level-2 main effect to see if historical inequality or institutional regime mattered more in fitting the model. M12 is M11 with Year removed to test if time adds any explanatory power beyond Inequality_growth.

\section{Results}


Table 2. Multilevel regression models of public support for social welfare.

\begin{tabular}{|c|c|c|c|c|c|c|c|}
\hline Model & Time & Country & $\begin{array}{c}\text { lrtest } \\
\text { p-value }\end{array}$ & AIC & $\begin{array}{l}\text { e.var time } \\
\text { (Level-1) }\end{array}$ & $\begin{array}{l}\text { e.var country } \\
\text { (Level-2) }\end{array}$ & $\mathrm{r}^{2}$ Level- $^{\mathrm{a}}$ \\
\hline MA & -- & -- & -- & 91,676 & 0.022 & 0.110 & -- \\
\hline MB & -- & -- & 0.000 & 89,568 & 0.022 & 0.085 & - \\
\hline M0 & - - & -- & -- & 1.20 & 0.021 & 0.085 & $4.4 \%$ \\
\hline M1 & Year & -- & 0.187 & 1.46 & 0.020 & 0.085 & $11.3 \%$ \\
\hline M2 & Year & Year (r.-slopes) & 0.087 & 0.32 & 0.012 & 0.089 & $47.3 \%$ \\
\hline M3 & Inequality_growth & -- & 0.110 & 0.65 & 0.019 & 0.086 & $14.3 \%$ \\
\hline M4 & Inequality_growth & $\begin{array}{l}\text { Inequality_growth } \\
\text { (r.-slopes) }\end{array}$ & 0.125 & 1.04 & 0.014 & 0.087 & $38.6 \%$ \\
\hline M5 & -- & $\begin{array}{l}\text { Inequality_growth } \\
\text { (r.-slopes) }+ \text { Year } \\
\text { (r.-slopes) }\end{array}$ & 0.088 & 1.67 & 0.013 & 0.088 & $42.6 \%$ \\
\hline M6 & -- & $\begin{array}{l}\text { Inequality_growth } \\
\text { (r.-slopes) }+ \text { Year } \\
\text { (r.-slopes) }+ \\
\text { Inequality_1980 }\end{array}$ & 0.033 & -1.53 & 0.013 & 0.057 & $42.6 \%$ \\
\hline M7 & Year + Inequality_growth & Inequality_1980 & 0.051 & -0.55 & 0.019 & 0.055 & $14.4 \%$ \\
\hline M8 & Year + Inequality_growth & Liberal & 0.417 & 4.36 & 0.019 & 0.084 & $14.3 \%$ \\
\hline M9 & $\begin{array}{l}\text { Year }+ \text { Inequality_growth }+ \\
\text { Inequality_1980* } \\
\text { Inequality_growth }\end{array}$ & Inequality_1980 & 0.069 & 0.50 & 0.018 & 0.055 & $17.9 \%$ \\
\hline M10 & $\begin{array}{l}\text { Year }+ \text { Inequality_growth }+ \\
\text { Liberal*Inequality_growth }\end{array}$ & Liberal & 0.069 & 0.49 & 0.015 & 0.085 & $33.6 \%$ \\
\hline M11 & $\begin{array}{l}\text { Year }+ \text { Inequality_growth }+ \\
\text { Liberal*Inequality_growth }\end{array}$ & Inequality_1980 & 0.009 & -4.43 & 0.015 & 0.057 & $33.6 \%$ \\
\hline M12 & $\begin{array}{l}\text { Inequality_growth }+ \\
\text { Liberal*Inequality_growth }\end{array}$ & Inequality_1980 & 0.007 & -4.97 & 0.016 & 0.056 & $29.3 \%$ \\
\hline
\end{tabular}

Note: MA and MB include individual-level (3-level model); M0-M11 are country-time (Level-1 after removing contextual effects) and country (Level-2) 2-level models adjusted for individual-level effects from MB to control for contextual effects; 'e.var' residual variance, 'p-value' significance of likelihood ratio test against M0.

a Percentage reduction in total variance of social welfare support at the time level (compared to empty-model MA) so that $4.4 \%$ refers to the amount that individual-level variables explain as composition effects at the country-time level (M0); values in italics produced from random-slopes models. 
The final column of Table 2 (' $\mathrm{r}^{2}$ Level-1') reveals that $4.4 \%$ of the country-time variance is a result of differing socio-economic and demographic compositions taken from individual-level data, i.e., contextual effects (M0), calculated as the per cent of the total level-1 variance it explains (e.g. Snijders \& Bosker, 1999). This is the variance parsed out of the model so as not to bias results. M0 sets a baseline AIC of 1.20 for comparison.

M1 tests H1 with a fixed-slope for Year. This model did not fit the data better than M0 according to an insignificant likelihood-ratio test p-value ('Irtest p-value') and no improvement in AIC. However, it is evidence that Year matters or correlates closely with something that matters, as it explains $6.9 \%$ of the variance in Support (after subtracting the $4.4 \%$ contextual effect explained by M0). Adding a random-slope for Year led to a marginally better fitting model with an lrtest $\mathrm{p}<0.10$ and a decrease in AIC (M2), but like M4-M6, this is not theorydriven and instead sets the maximum amount of variance explainable by these variables (datadriven slope fitting). Inequality_growth as a level-1 variable did not improve M3 over M0 similar to M1. That the different configurations of random-slopes in M4-M6 only led to small increases in $\mathrm{r}^{2}$ demonstrates the endogeneity between Year and Inequality_growth (correlation=0.65). The maximum data-driven explanatory power comes from M5 and $\mathrm{M} 6^{5}$ at $42.6 \%$ of the level-2 variance. This set a baseline to compare further models.

An independent fixed-slope for Year, Inequality growth and Inequality 1980 in M7 fit the data significantly better than M0; lrtest p-value<0.10. It also showed improvement in AIC and explained $14.4 \%$ of the variance in Support at level-2. This is a formidable sized variance reduction from $\mathrm{M} 0$, and supportive of the idea that these variables are important theoretical explanations of Support, including a negative signed coefficient for Inequality_1980 supporting H2. Table A2 in the Appendix offers coefficients and demonstrates that the effect of Inequality_growth was negative. This is specialised support of H1. It is not the time trend that

\footnotetext{
${ }^{5}$ M6 does not increase the level-2 $\mathrm{r}^{2}$ because the added variable is a level-3 variable which cannot explain any level-2 variance.
} 
matters, but how much inequality grew with time. It suggests that the public move with inequality, so that they get what they want or prefer what they get. We also modelled M8 with a country-level measure of Liberal instead of Inequality_1980, but this was not an improvement, although the negative coefficient also supports H2. This pre-empted our choice to use Inequality_1980 as the preferred level-2 variable in M11 and M12.

Next, we tested H3 by adding an interaction of Inequality_1980 with Inequality_growth (M9). Although this is an 'ok' fitting model with $\mathrm{p}<0.10$ and an additional $3.5 \%$ of variance explained, it did not fit better than M7. Testing H3 in alternative form using Liberal instead of Inequality_1980 in M10 showed slight improvement although still some ill-fit. A key bit of information fell out of M10: the Liberal*Inequality_growth interaction boosted the $\mathrm{r}^{2}$ up to $33.6 \%$ from $14.4 \%$ in M7. This theoretically driven model accounted for $78 \%$ of the maximum possible explained variance by all these variables at level-1 (net of the $4.4 \%$ explained by composition). Even with such a small sample, this is a massive jump. The results favour Liberal vs. Inequality_growth as the preferred explanatory historical institutions variable (which variant of $\mathrm{H} 2$ mattered more). However, the gravity of our finding actualised in M11 where we modelled Liberal as our interaction with Inequality_growth at level-1, motivated by our results in M8, and used Inequality_1980 as our main effect variable at level-2, motivated by M7 and M8. M11 fit far better than all others did with a highly significant lrtest $(\mathrm{p}<0.01)$ and a formidable reduction in AIC (roughly 5 points). This points toward a unique role of both historical inequality and institutions. The effect of Year could safely be removed from M11 leading to M12 where we found large and significant coefficients (Table A2 in the Appendix) and after interaction calculations there was a positive effect in liberal societies (Liberal=1) of Inequality_growth on support for social welfare and a negative effect in social/coordinated societies (Liberal=0). Although the level-1 variance and effects in M10 were unchanged in M11 and M12, the latter model showed that level-2 was the source of ill-fit in M10. Therefore, we found conclusive support of H3. Figure 2 reports marginal predicted support from M12 with a 
negative, significant slope difference for Liberal (dashed line) and non-Liberal (solid line) (see Appendix Figure A1, for scatterplots).

Figure 2. Public support for social welfare by historical inequality regime type and inequality growth since 1980, ISSP 1985-2006 data.

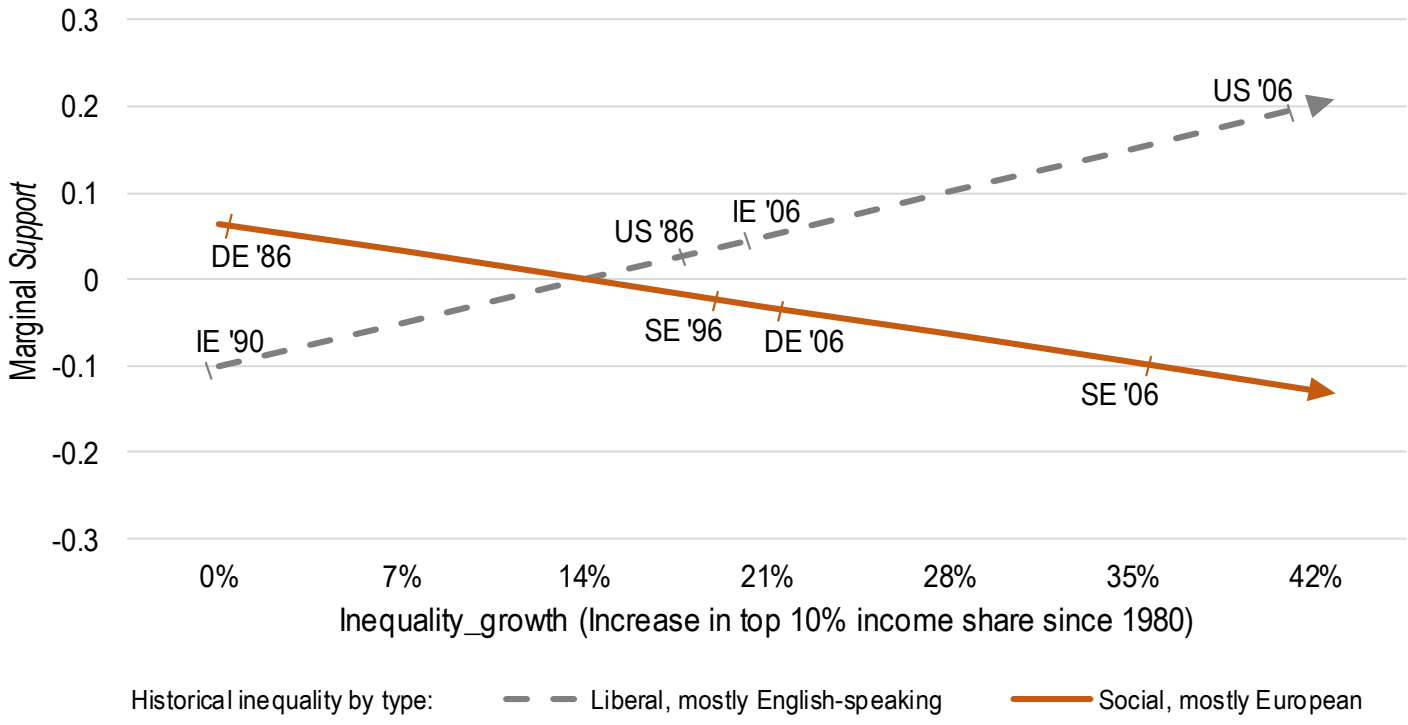

Note: 13 countries from Figure 1, estimates from Table 4, ISSP data 1985-2006, WID data 1980-2006, Historical type refers to regime dichotomy (Liberal are OZ, CN, IE, NZ, GB and US; social are JP, FR, $\mathrm{DE}(\mathrm{W} \& \mathrm{E}), \mathrm{NO}, \mathrm{SE}$ and $\mathrm{CH})$. Hash marks demonstrate marginal inequality and attitude change between two time points in four countries.

Even though Year does not matter much in our models, Figure 2 shows how much Inequality_ growth matters and how this predicted a change in public opinion. Although the slopes are clear and evidence of large mathematical effects, we added two countries to the figure where inequality grew little at first since 1980 and then shot upward through around turn of the Millennium (Ireland and Western Germany). We also added two countries where it grew substantially since 1980 and continued growing (Sweden and the United States). These marginal country-predictions demonstrate how the regression estimates link to the real-world data in both regime types. On average, the Liberal societies increase support in opposition to inequality growth and the non-Liberal societies decrease support in the same direction as inequality growth. 


\section{Sensitivity analysis}

Given the lack of cases at the country-level we humbly remind the reader that we cannot make population-inferential arguments using our statistical results. Again, countries are not a 'sample' of a 'normally distributed' population like humans. Nonetheless, we offer some sensitivity tests to improve the qualitative interpretation of our quantitative findings. First we engaged in a power analysis to see how reliable our significance tests were if we simply leave aside the lack of normal distributional assumptions. These results in Table A3 in the Appendix demonstrate that we have a range of potential power to identify a true effect behind a regression slope at the country-level. For example, if the true effect is medium or large we achieve power over 0.950; however, if the true effect is small or medium with very high error reliability this drops below 0.800 . We do not know the true effect and we lack an experimental setting, therefore our work here is largely exploratory.

In the lower part of Table A3 we report results from a Bayesian credible interval analysis. Stegmueller (2013) tested Bayesian credible intervals for small-n multilevel models, showing that it offers increased reliability. Not surprisingly, the standard errors explode in the Bayesian analysis. Only the Inequality_1980 variable remains significant in M12 (and most other models). This points us to lack of inferential power. We have large effect sizes, but lack the observational degrees of freedom to rely on inferential statistics. We consider these effect sizes as evidence on top of model fitting pointing toward our theoretical perspective on the limits of inequality. It is precisely this theoretical perspective that we hope inspires further research and helps explain some of what we observe in rich democracies as they continue their increasing inequality trajectories.

Finally, following Bryan and Jenkins (2016) we correlated our two variables of interest at the country-level Liberal and Inequality_1980 with random-slopes (i.e., fixed-effects) calculated in M2 for Time and M4 for Inequality_growth. Results in Table A4 show strong ( 0.5) correlations between the Time and the Inequality_growth coefficients and the variable 
Liberal. We find smaller positive correlations of the coefficients with Inequality_1980. This demonstrates that liberal countries have more positive slopes and social/coordinated countries more negative slopes. It also shows that Liberal and Inequality_1980 are almost perfectly uncorrelated. This supports our preferred theoretical model suggesting that both historical inequality levels and the type of capitalist/welfare state institutions uniquely matter for public opinion.

\section{Other limitations}

We could not model the range or complexity of things that confound inequality, meaning we were not performing a strictly causal test (Elwert, 2013). Adding more variables was not a viable option with so few cases and because measures of societies, such as Gross Domestic Product, social spending or democracy as endogenous with each other and public opinion (Breznau, 2017; Breznau et al., 2011; Pierson, 2004; Sundberg \& Taylor-Gooby, 2013). We aimed to reduce the range of potential theoretical explanations of the inequality-opinion link, thus effects we found are total and inclusive of several indirect causes and potential loops.

The measure of Inequality_growth is highly endogenous with Year as inequality increased in a linear fashion across years in all but one country (France). Thus, we cannot know, causally speaking, if time or inequality drove the effect. Yet we have strong evidence that it derives from income inequality, not time, because income inequality growth had far greater predictive power in the model that included a year variable (M11); and the year variable could be removed from the model without losing this predictive power, resulting in an increase in model fit (M12) as shown in Table 2. A crucial limitation is that inequality is likely both a cause and a consequence of public preferences and with only 13 cases and two time points we have no chance to tackle this issue even with sophisticated sensitivity analyses, when preferences and inequality move in tandem we assume but cannot observe reciprocal causes. 


\section{Discussion}

Using ISSP and WID data from 1980-2006, we found that changes in the income distribution link to changes in public support for social welfare. In liberal societies mostly of the Englishspeaking diaspora, we found that increases in inequality predict higher levels of support for social welfare, whereas coordinated and social democratic societies mostly in Europe showed that inequality growth predict lower levels of support. The latter case may indicate that individuals in more social-oriented societies want liberalisation and are getting what they want. They experience the limits of equality and shift their opinion in a liberal direction. Those in liberal societies do not want (any more) inequality and experience the limits of inequality. These limits depend on historical inequality in each society. Publics living in countries that had higher concentrations of income in 1980 show lower support for social welfare, presumably out of path dependency. This is an effect that is independent of liberal or coordinated institutional types, and is an important finding that explains different trajectories of countries nested in each type.

We suggest that there are varieties of public responsiveness to liberalisation, just as others suggest varieties of liberalisation trajectories (Thelen, 2014). After all, liberalisation of the welfare state, including failures to adapt to globalisation and financialisation, are one cause of increases in inequality ${ }^{6}$. This fits with research that suggests that it is not only the level but also the type of inequality, as well as the institutional or historical context, that matter for public opinion and the direction policy change takes (Béland, 2007; Hacker \& Pierson, 2010; Lupu \& Pontusson, 2011).

There are many under-explained patterns of social welfare and inequality attitudes across countries that might be a product of an inequality and institutional context interaction (Jæger, 2006; Kelley \& Evans, 1993; Schmidt-Catran 2016). Possibly the government becomes

\footnotetext{
${ }^{6}$ Although not the only cause (Atkinson, 2015; Therborn, 2013)
} 
more responsive to the wealthy when there is a higher concentration of wealth at the top, thereby explaining the liberalisation trajectories of the liberal states (Scruggs \& Hayes, 2017). This calls for more sociological research with an eye on public opinion (Burstein, 1998; Manza \& Brooks, 2012). Although we identified only two 'types' of potential public responsiveness (liberal/liberalised vs. social/liberalising), we hope this has planted seeds for future research. It also reminds us of the limits of macro-institutional research, as things are difficult to disentangle when countries are the units of analysis. We cannot sort out social norms, legal institutions, corporatism, history and culture in the linkages between inequality, policy and opinions (Arts \& Gelissen, 2002; Castles \& Mitchell, 1993; Hall \& Soskice, 2001; van Oorschot, 2007).

Our findings suggest that the social welfare states of Europe are able to absorb some degree of liberalisation without large subjective changes to the quality of life for those at the lower end of the income distribution, or without pushing them so far as to show negative responsiveness. This may be due to unions and wage-bargaining as strong factors in Europe (Ebbinghaus \& Visser, 1999; Kristal \& Cohen, 2017). In liberal societies such as the United States, further liberalisations excessively harm members of the public; they are subjectively 'dishevelled' (Pickett \& Wilkinson, 2015; Wilkinson \& Pickett, 2009). A prediction from this finding would be that the government in liberal societies begins reversing liberalisation trajectories through democratic processes or in response to civil strife produced by the social ills of extreme inequality. This is not what we have observed so far; inequality marches forth in places such as the US and the UK. Perhaps this is a dual product of entrenched elite interests which were able to use the tools of liberal democracy to slowly develop plutocratic states (Gilens \& Page, 2014; Scruggs \& Hayes, 2017) and a powerful and privatised media market that shapes public preferences or simply distracts the public from stagnating wages and other material loses (Piketty \& Saez, 2003).

Looking at social Europe in contrast, it seems that individuals have reached the limits of equality, and are increasingly favouring the idea that removing government welfare and 
redistribution will improve society, i.e., through economic growth. In the more absolute equality countries, such as Sweden, this seems inevitable, or perhaps a ceiling effect occurs as hyper-equalitarian institutions meet Europeanisation and globalisation (Korpi, 2003; Offe, 2003). Moreover, historically Swedes are accustomed to low levels of inequality, so public attitudes have changed from being supportive of social welfare to being slightly less supportive, without favouring 'full-on' neo-liberalism.

We also considered an alternative explanation in Pontusson and Lupo (2011) and Iversen and Soskice (2006), who suggest that voters in the middle of the income distribution favour less redistribution in the face of more inequality. Inequality shifts social and economic capital (power) to favour elites. Therefore, the middle classes, in particular in multi-party systems, have rational interests in allying with elites to gain power in opposition to the lower income classes, a thesis supported by the research of Kelly and Enns (2010) and reflective of our limits of equality findings herein. From this perspective, we would expect retrenchments to continue in European welfare states, perhaps until income inequality reaches a certain threshold and the middle classes, if not the public in general, are 'burned out' (Therborn, 2013). The tight link between states, parties and special actors in the corporatist European and Japanese contexts provides a scenario where power constellations are predetermined. Thus, the seats at the collective bargaining table fill increasingly with individual members of the elite - educated, higher income, politically active families - having elite interests in mind even when sitting in a union bargaining or left-party role, leading to what some label partyocracy (Kuhner, 2016).

European immigration contexts are a potential confounder leading individuals to want more government intervention in welfare and redistribution for themselves but preferring not to waste their group resources on immigrants. This welfare chauvinism is untenable politically and tends to leave the public instead with reduced support for the universal welfare state (Eger \& Breznau, 2017). With 'partyocracy' and populism movements, liberalisation becomes increasingly possible (Röth, Afonso \& Spies, forthcoming). However, the parties must convince 
the public that these policies are necessary, again keeping the causal arrow pointing at a public 'reaction' to, or persuasion 'as a result of', inequality (Schumacher, Vis, \& van Kersbergen, 2013). In all likelihood, the arrow is reciprocal (Breznau, 2017), but we cannot sort this out in this small dataset.

Wanting less government intervention in the economy is not synonymous with wanting more income inequality. For example, evidence suggests that public attitudes toward income inequality are biased by perceptions that higher earners should get less, but not necessarily that the poor should get more (Christopher \& Schlenker, 2000; Walsh, 2008). This might explain the somewhat puzzling question of why the public is, as we found, increasingly opposed to income inequality (Schmidt-Catran, 2016) while at the same time increasingly opposed to government intervention in social welfare in the European context. Although scholars clearly see the causal relationship between liberalisation and income inequality, members of the public may not engage this linkage cognitively when forming opinions and policy preferences (Gugushvili, 2015; Kenworthy, 1999; Kwon, 2016; OECD, 2008; Pickett \& Wilkinson, 2015). Therefore, support for liberalisation may derive in part from public lack of knowledge on what is at stake.

\section{Acknowledgements}

The Bremen International Graduate School of Social Sciences at the University of Bremen, Germany; the German Institute for Japanese Studies, Tokyo, Japan; and Hokkaido University, Sapporo, Japan supported parts of this research. 


\section{References}

Arts, W. \& Gelissen, J. (2001). Welfare states, solidarity and justice principles: Does the type really matter? Acta Sociologica, 44(4), 283-299.

Arts, W. \& Gelissen, J. (2002). Three worlds of welfare capitalism or more? A state-of-the-art report. Journal of European Social Policy, 12(2), 137-158.

Atkinson, A. B. (2015). Inequality what can be done? Cambridge, MA: Harvard University Press.

Bartels, L. M. (1986). Issue voting under uncertainty: An empirical test. American Journal of Political Science, 30(4), 709-728.

Bean, C. \& Papadakis, E. (1998). A comparison of mass attitudes towards the welfare state in different institutional regimes, 1985-1990. International Journal of Public Opinion Research, 10(3), 211-236.

Beckfield, J., Bambra, C., Eikemo, T., Huijts, T., McNamara, C., \& Wendt, C. (2015). An institutional theory of welfare state effects on the distribution of population health. Social Theory \& Health 13(3), 227-244.

Béland, D. (2007). Ideas and institutional change in social security: Conversion, layering, and policy drift. Social Science Quarterly, 88(1), 20-38.

Bendz, A. (2015). Paying attention to politics: Public responsiveness and welfare policy change. Policy Studies Journal, 43(3), 309-332.

Bourdieu, P. (1984). Distinction: A social critique of the judgement of taste. London: Routledge.

Brady, D. 2009. Rich democracies, poor people. How politics explains poverty. Oxford: Oxford University Press.

Breznau, N. (2015). The missing main effect of welfare state regimes: A replication of 'Social Policy Responsiveness in Developed Democracies' by Brooks and Manza. Sociological Science, 2, 420-441.

Breznau, N. (2017). Positive returns and equilibrium: Simultaneous feedback between public opinion and social policy. Policy Studies Journal, 45(4), 583-612.

Breznau, N. \& Eger, M. A. (2016). Immigrant presence, group boundaries, and support for the welfare state in western european societies. Acta Sociologica 59(3):195-214.

Breznau, N., Lykes, V. A., Kelley, J., \& Evans, M. D. R. (2011). A clash of civilizations? Preferences for religious political leaders in 86 nations. Journal for the Scientific Study of Religion, 50(4), 671-691.

Bryan, M. \& Jenkins, S. P. (2016). Multilevel modelling of country effects: A cautionary tale. European Sociological Review, 32(1), 3-22.

Burstein, P. (1998). Bringing the public back in: should sociologists consider the impact of public opinion on public policy? Social Forces, 77(1), 27-62.

Castles, F. G. (1993). Families of nations: Patterns of public policy in Western democracies. Hanover, NH: Dartmouth University Press.

Castles, F. G. \& Mitchell, D. (1993). Worlds of welfare and families of nations. In: F. G. Castles (Ed.), Families of nations: Patterns of public policy in western democracies (pp. 93-128). Burlington, VT, USA: Dartmouth Publishing Company.

Chen, F., Curran, P. J., Bollen, K. A., Kirby, J., \& Paxton, P. (2008). An empirical evaluation of the use of fixed cutoff points in RMSEA test statistic in structural equation models. 
Sociological Methods \& Research, 36(4), 462-494.

Christopher, A. N. \& Schlenker, B. R. (2000). The impact of perceived material wealth and perceiver personality on first impressions. Journal of Economic Psychology, 21(1), 1-19.

DiPrete, T. A. \& Eirich, G. M. (2006). Cumulative advantage as a mechanism for inequality: A review of theoretical and empirical developments. Annual Review of Sociology, 32, 271297.

Ebbinghaus, B. \& Visser, J. (1999). When institutions matter - union growth and decline in Western Europe, 1950-1995. European Sociological Review 15(2):135-58.

Eger, M. A. \& Breznau, N. (2017). Immigration and the welfare state: A cross-regional analysis of European welfare attitudes. International Journal of Comparative Sociology 58(5):440-63.

Elwert, F. (2013). Graphical causal models. Pp. 245-72 in Handbook of causal analysis for social research, edited by S. L. Morgan. Dordrecht, The Netherlands: Springer Science \& Business Media.

Esping-Andersen, G. (1989). The three political economies of the welfare state. Canadian Review of Sociology 26(1):10-36.

Esping-Andersen, G. (1996). After the golden age? Welfare state dilemmas in a global economy. In: G. Esping-Andersen (Ed.), Welfare states in transition: National adaptations in global economies (pp. 1-31). Thousand Oaks, CA: Sage Publications.

Ganzeboom, H. B. G., De Graaf, P. M., \& Treiman, D. J. (1992). A standard international socio-economic index of occupational status. Social Science Research 21(1):1-56.

Gilens, M. (2009). Why Americans hate welfare: Race, media, and the politics of antipoverty policy. Chicago, IL: The University of Chicago Press.

Gilens, M. \& Page, B. I. (2014). Testing theories of American politics: Elites, interest groups, and average citizens. Perspectives on Politics 12(3), 564-581.

Gugushvili, A. (2015). Economic liberalization and intergenerational mobility in occupational status. Comparative Sociology 14(6), 790-820.

Habermas, J. (1989). The structural transformation of the public sphere: An inquiry into a category of bourgeois society. English Tr. edited by T. Burger \& F. Lawrence. Cambridge, MA: MIT Press.

Hacker, J. S. \& Pierson, P. (2010). Winner-take-all politics: Public policy, political organization, and the precipitous rise of top incomes in the United States. Politics \& Society 38(2), 152-204.

Hall, P. A. \& Soskice, D. (2001). An introduction to varieties of capitalism. In: P. A. Hall \& D. Soskice (Eds.), in Varieties of Capitalism. The Institutional Foundations of Comparative Advantage (pp. 1-68). Oxford: Oxford University Press.

Hall, P. A. \& Thelen, K. (2009). Institutional change in varieties of capitalism. SocioEconomic Review, 7(1), 7-34.

Kim, H., Huh, S., Choi, S., \& Lee, Y. (2017). Perceptions of Inequality and Attitudes towards Redistribution in Four East Asian Welfare States. International Journal of Social Welfare, 27(1), 28-39.

Hayduk, L. A., Cummings, G., Kwame, B., Pazderka-Robinson,H., \& Boulianne, S. (2007). Testing! Testing! One, two, three - testing the theory in structural equation models! Personality and Individual Differences, 42(5), 841-850.

Hox, J. J. (2010). Multilevel analysis: Techniques and applications (2nd ed.) New York: 
Routledge.

Iversen, T. \& Soskice, D. (2006). Electoral institutions and the politics of coalitions: Why some democracies redistribute more than others. American Political Science Review, $100(2), 165-181$.

Jæger, M. M. (2006). Welfare regimes and attitudes towards redistribution: The regime hypothesis revisited. European Sociological Review, 22(2), 157-170.

Jæger, M. M. (2009). United but divided: Welfare regimes and the level and variance in public support for redistribution. European Sociological Review, 25(6), 723-737.

Kelley, J. \& Evans, M. D. R.. (1993). The legitimation of inequality: Occupational earnings in nine nations. American Journal of Sociology, 99(1), 75-125.

Kelly, N. J. \& Enns, P. K. (2010). Inequality and the dynamics of public opinion: The selfreinforcing link between economic inequality and mass preferences. American Journal of Political Science, 54(4), 855-870.

Kenworthy, L. (1999). Do social-welfare policies reduce poverty? A cross-national assessment. Social Forces, 77(3), 1119-1139.

Kline, R. B. (2011). Principles and practice of structural equation modeling. 3rd Edition. New York, NY: Guilford Press.

Korpi, W. (2003). Welfare state regress in Western Europe: Politics, institutions, globalization, and Europeanization. Annual Review of Sociology, 29(1), 589-609.

Kristal, T. \& Cohen, Y. (2017). The causes of rising wage inequality: The race between institutions and technology. Socio-Economic Review, 15(1),187-212.

Krueger, A. (2012). The rise and consequences of inequality. Washington, DC: Center for American Progress. Council of Economic Advisers, talk delivered on Jan. 12th, 2012.

Kuhner, T. K. (2016). Plutocracy and partyocracy: Oligarchies born of constitutional interpretation. Review of Constitutional Studies, 21, 115-142.

Kwon, R. (2016). Can we have our cake and eat it too? Liberalization, economic growth, and income inequality in advanced industrial societies. Social Forces, 95(2), 469-502.

Leibfried, S. \& Mau, S. (2008). Introduction. In: S. Leibfried \& S. Mau (Eds.), Welfare states: construction, deconstruction,rReconstruction. Volume I, analytical approaches (pp. xilxiv). Cheltenham, UK: Edward Elgar Publishing.

Lewis, J. (2001). The decline of the male breadwinner model: Implications for work and care. Social Politics: International Studies in Gender, State \& Society, 8(2), 152-169.

Linos, K. \& West, M. (2003). Self-interest, social beliefs, and attitudes to redistribution. Readdressing the issue of cross-national variation. European Sociological Review, 19(4), 393-409.

Lupu, N. \& Pontusson, J. (2011). The structure of inequality and the politics of redistribution. American Political Science Review, 105(2), 316-336.

Manza, J. \& Brooks, C. (2012). How sociology lost public opinion: A genealogy of a missing concept in the study of the political. Sociological Theory, 30(2), 89-113.

Mau, S. (2004). Welfare regimes and the norms of social exchange. Current Sociology, 52(1), 53-74.

Obinger, H., Schmitt, C., \& Zohlnhöfer, R. (2014). Partisan politics and privatization in OECD countries. Comparative Political Studies, 47(9), 1294-1323.

OECD. (2008). Growing unequal? Income distribution and poverty in OECD countries. Paris: Organization for Economic Cooperation and Development. 
Offe, C. (2003). The European model of 'social' capitalism: Can it survive European integration? Journal of Political Philosophy, 11(4), 437-469.

Okun, A. M. (1975). Equality and efficiency: The big tradeoff. Washington D.C.: The Brookings Institution.

van Oorschot, Wim. (2007). Culture and social policy: A developing field of study. International Journal of Social Welfare, 16(2), 129-139.

Orloff, A. S. \& Skocpol, T. (1984). Why not equal protection? Explaining the politics of public social spending in britain, 1900-1911, and the United States, 1880s-1920. American Sociological Review, 49(6), 726-750.

Patashnik, E. M. \& Zelizer, J. E. (2013). The struggle to remake politics: Liberal reform and the limits of policy feedback in the contemporary American state. Perspectives on Politics, 11(4), 1071-1087.

Pickett, K. \& Wilkinson, R.. (2015). Income inequality and health: A causal review. Social Science \& Medicine, 128, 316-326.

Pierson, P. (1996). The new politics of the welfare state. World Politics, 48(2), 143-179.

Pierson, P. (2000). Increasing returns, path dependence, and the study of politics. The American Political Science Review, 94(2), 251-267.

Pierson, P. (2002). Coping with permanent austerity: Welfare state restructuring in affluent democracies. Revue française de sociologie, 43(2), 369-406.

Pierson, P. (2004). Politics in time: History, institutions and social analysis. Princeton, NJ: Princeton University Press.

Piketty, T. (2014). Capital in the Twenty-First Century. Cambridge, MA: Harvard University Press.

Piketty, T. \& Saez, E. (2003). Income inequality in the United States: 1913-1998. Quarterly Journal of Economics, 118(1), 1-41.

Roberts, B. M. \& Saeed, M. A. (2012). Privatizations around the world: Economic or political determinants? Economics \& Politics, 24(1), 47-71.

Röth, L., Afonso, A., \& Spies, D. C. (Forthcoming). The Impact of Populist Radical Right Parties on Socio-Economic Policies. European Political Science Review.

Schmidt-Catran, A. W. (2016). Economic inequality and public demand for redistribution: Combining cross-sectional and longitudinal evidence. Socio-Economic Review, 14(1), 119-140.

Schumacher, G., Vis, B., \& van Kersbergen, K. (2013). Political parties' welfare image, electoral punishment and welfare state retrenchment. Comparative European Politics, 11(1), 1-21.

Scruggs, L. \& Hayes, T. J. (2017). The influence of inequality on welfare generosity. Politics \& Society, 45(1), 35-66.

Snijders, T. A. B. \& Bosker, R. J. (1999). Multilevel analysis: An introduction to basic and advanced multilevel modeling. London/Thousand Oaks: Sage Publications.

Soroka, S. N. \& Wlezien, C. (2010). Degrees of democracy: Politics, public opinion and policy. Cambridge: Cambridge University Press.

Soss, J. \& Schram, S. F. (2007). A public transformed? Welfare reform as policy feedback. The American Political Science Review, 101(1), 111-127.

Stegmueller, D. (2013). How many countries for multilevel modeling? A comparison of frequentist and Bayesian approaches. American Journal of Political Science, 57(3), 
748-761.

Sundberg, T. \& Taylor-Gooby, P. (2013). A systematic review of comparative studies of attitudes to social policy. Social Policy \& Administration, 47(4), 416-433.

Svallfors, S. (1997). Worlds of welfare and attitudes to edistribution: A comparison of eight western nations. European Sociological Review, 13(3), 283-304.

Thelen, K. (2014). Varieties of liberalization and the new politics of social solidarity. Cambridge: Cambridge University Press.

Therborn, G. (2013). The killing fields of inequality. Cambridge: Polity Press.

Walsh, J. P. (2008). CEO Compensation and the responsibilities of the business scholar to society. Academy of Management Perspectives, 22(2), 26-33.

Weakliem, D. L. (2016). The missing main effect of welfare state regimes: A comment. Sociological Science.

Weakliem, D. L., Andersen, R., \& Heath, A. F. (2005). By popular demand: The effect of public opinion on income inequality. Comparative Sociology, 4, 261-284.

Wegener, B. \& Liebig, S. (1995). Dominant ideologies and the variation of distributive justice norms: A comparison of East and West Germany, and the United States. In: D. S. M. James, R. Kluegel, \& B. Wegener, Social Justice and Political Change: Public Opinion in Capitalist and Post-Communist States (pp. 239-262 ). Hawthorne, NY: Aldine de Gruyter.

WID. 2017. World inequality database. Paris: The World Inequality Lab. Retrieved from http://wid.world/data/.

Wilensky, H. L. (1975). The welfare state and equality: Structural and ideological roots of public expenditure. Berkeley, CA: University of California Press.

Wilkinson, R. \& Pickett, K. (2009). Income inequality and social dysfunction. Annual Review of Sociology, 35, 493-511. 


\section{Appendix}

Table A1. Measurement of the dependent variable, public support for social welfare.

\begin{tabular}{|c|c|c|c|c|c|c|c|c|}
\hline \multicolumn{2}{|c|}{ Variables } & \multirow{2}{*}{$\begin{array}{l}\text { Betas } \\
\text { Latent }\end{array}$} & \multicolumn{6}{|c|}{ Correlations } \\
\hline Label & Measure & & Latent & $\mathrm{i}-1$ & $\mathrm{i}-2$ & $\mathrm{i}-3$ & $\mathrm{i}-4$ & i-5 \\
\hline Latent & $\begin{array}{l}\begin{array}{l}\text { Support } \\
\text { (for social }\end{array} \\
\text { welfare) } \\
\text { Government } \\
\text { should: }\end{array}$ & -- & 1 & & & & & \\
\hline item-1 & regulate prices & 0.230 & 0.661 & 1 & & & & \\
\hline item-2 & provide health & 0.324 & 0.783 & 0.368 & 1 & & & \\
\hline item-3 & $\begin{array}{l}\text { care for aged } \\
\text { provide }\end{array}$ & 0.351 & 0.805 & 0.359 & 0.608 & 1 & & \\
\hline item-4 & unemployment & 0.207 & 0.625 & 0.304 & 0.327 & 0.381 & 1 & \\
\hline \multirow[t]{7}{*}{ item-5 } & provide jobs & 0.264 & 0.689 & 0.447 & 0.342 & 0.351 & 0.414 & 1 \\
\hline & Model test & Statistic & & & & & & \\
\hline & $\begin{array}{l}\text { Scale reliability } \\
\text { alpha }\end{array}$ & 0.727 & & & & & & \\
\hline & Exact fit $p$-value & $0.000^{\mathrm{a}}$ & & & & & & \\
\hline & $\operatorname{RMSEA}(p)$ & $0.078(0.081)$ & & & & & & \\
\hline & CFI & 0.980 & & & & & & \\
\hline & TLI & 0.950 & & & & & & \\
\hline
\end{tabular}

Note: All code and technical details available in online appendix (https://osf.io/m3zwv/). Principal factor and principal components analyses lead to predicted values correlating at 0.99 . We take the former as our predictive measurement of the dependent variable Support. Chi-square and fit statistics taken from a structural measurement model of individual-level variance of items loading on the latent.

${ }^{a}$ For two reasons we did not expect to reject the exact fit hypothesis: (1) Our measurement of public opinion is causal but contains approximate errors we cannot model in the regression because there are not enough df due to 13 country-cases. (2) Individual cases after listwise deletion are 79,475 leaving room for measurement error among unobserved confounders. This is a well-known feature of the chi-square test statistic as N increases (Kline 2011: p.201). Other fit statistics are strong and lead us to accept this as the best possible means for measuring our dependent variable. 
Table A2. Regression results for multilevel models of public support for social welfare, as listed in Table 2

Fixed-slopes coefficients

\begin{tabular}{|c|c|c|c|c|c|c|c|c|c|c|}
\hline Model & Intercept & Year & $\begin{array}{l}\text { Ineq.-- } \\
\text { growth }\end{array}$ & $\begin{array}{c}\text { Ineq.-- } \\
1980 \\
\end{array}$ & $\begin{array}{l}\text { Lib- } \\
\text { eral }\end{array}$ & $\begin{array}{l}\text { Ineq._growth } \\
* \text { Ineq._1980 } \\
\end{array}$ & $\begin{array}{c}\text { Ineq._growth* } \\
\text { Liberal }\end{array}$ & Intercept & Year & $\begin{array}{l}\text { Ineq.- } \\
\text { growth }\end{array}$ \\
\hline M0 & $\begin{array}{l}0.364 \\
(0.08)\end{array}$ & & & & & & & $\begin{array}{l}0.085 \\
(0.04)\end{array}$ & & \\
\hline M1 & $\begin{array}{l}0.364 \\
(0.08)\end{array}$ & $\begin{array}{l}-0.005 \\
(0.00)\end{array}$ & & & & & & $\begin{array}{l}0.085 \\
(0.04)\end{array}$ & & \\
\hline M2 & $\begin{array}{l}0.363 \\
(0.08)\end{array}$ & $\begin{array}{l}-0.005 \\
(0.00)\end{array}$ & & & & & & $\begin{array}{l}0.088 \\
(0.04)\end{array}$ & $\begin{array}{l}0.000 \\
(0.00)\end{array}$ & \\
\hline M3 & $\begin{array}{l}0.364 \\
(0.08)\end{array}$ & & $\begin{array}{l}-0.372 \\
(0.23)\end{array}$ & & & & & $\begin{array}{l}0.086 \\
(0.04)\end{array}$ & & \\
\hline M4 & $\begin{array}{l}0.363 \\
(0.08)\end{array}$ & & $\begin{array}{l}-0.296 \\
(0.03)\end{array}$ & & & & & $\begin{array}{l}0.087 \\
(0.04)\end{array}$ & $\begin{array}{l}0.381 \\
(0.39)\end{array}$ & \\
\hline M5 & $\begin{array}{l}0.363 \\
(0.08)\end{array}$ & & & & & & & $\begin{array}{l}0.088 \\
(0.04)\end{array}$ & $\begin{array}{l}0.000 \\
(0.00)\end{array}$ & $\begin{array}{l}0.159 \\
(0.46)\end{array}$ \\
\hline M6 & $\begin{array}{l}0.966 \\
(0.25)\end{array}$ & & & $\begin{array}{l}-8.616 \\
(3.41)\end{array}$ & & & & $\begin{array}{l}0.057 \\
(0.02)\end{array}$ & $\begin{array}{l}0.000 \\
(0.00)\end{array}$ & $\begin{array}{l}0.159 \\
(0.46)\end{array}$ \\
\hline M7 & $\begin{array}{l}0.967 \\
(0.25)\end{array}$ & $\begin{array}{l}-0.000 \\
(0.00)\end{array}$ & $\begin{array}{l}-0.346 \\
(0.38)\end{array}$ & $\begin{array}{l}-8.621 \\
(3.41)\end{array}$ & & & & $\begin{array}{l}0.055 \\
(0.02)\end{array}$ & & \\
\hline M8 & $\begin{array}{l}0.405 \\
(0.11)\end{array}$ & $\begin{array}{l}-0.000 \\
(0.01)\end{array}$ & $\begin{array}{l}-0.346 \\
(0.38)\end{array}$ & & $\begin{array}{l}-0.089 \\
(0.17)\end{array}$ & & & $\begin{array}{l}0.084 \\
(0.04)\end{array}$ & & \\
\hline M9 & $\begin{array}{l}0.967 \\
(0.25)\end{array}$ & $\begin{array}{l}-0.002 \\
(0.01)\end{array}$ & $\begin{array}{l}-0.971 \\
(0.74)\end{array}$ & $\begin{array}{l}-8.621 \\
(3.41)\end{array}$ & & $\begin{array}{l}11.451 \\
(11.64)\end{array}$ & & $\begin{array}{l}0.055 \\
(0.02)\end{array}$ & & \\
\hline M10 & $\begin{array}{l}0.404 \\
(0.11)\end{array}$ & $\begin{array}{l}-0.006 \\
(0.01)\end{array}$ & $\begin{array}{l}-0.458 \\
(0.34)\end{array}$ & & $\begin{array}{l}-0.089 \\
(0.17)\end{array}$ & & $\begin{array}{l}1.179 \\
(0.46)\end{array}$ & $\begin{array}{l}0.085 \\
(0.04)\end{array}$ & & \\
\hline M11 & $\begin{array}{l}0.966 \\
(0.25)\end{array}$ & $\begin{array}{l}-0.006 \\
(0.01)\end{array}$ & $\begin{array}{l}-0.458 \\
(0.34)\end{array}$ & $\begin{array}{l}-8.619 \\
(3.41)\end{array}$ & & & $\begin{array}{l}1.179 \\
(0.46)\end{array}$ & $\begin{array}{l}0.056 \\
(0.02)\end{array}$ & & \\
\hline M12 & $\begin{array}{l}0.967 \\
(0.25)\end{array}$ & & $\begin{array}{l}-0.719 \\
(0.26) \\
\end{array}$ & $\begin{array}{l}-8.619 \\
(3.41) \\
\end{array}$ & & & $\begin{array}{l}0.965 \\
(0.43)\end{array}$ & $\begin{array}{l}0.056 \\
(0.02) \\
\end{array}$ & & \\
\hline
\end{tabular}

Note: Ineq. = 'Inequality'; Fixed-slopes also known as 'random-effects'; Random-slopes also known as 'fixedeffects'. variance

Random-slopes coeff. 
Table A3. Sensitivity tests: power analysis and MCMC sensitivity analyses.

Power to detect a bivariate standardized regression slope given error level

\begin{tabular}{lccccc}
$\begin{array}{l}\text { Test by } \\
\text { sample }\end{array}$ & $\mathrm{N}$ & $\begin{array}{c}\text { Tiny effect } \\
\text { (beta=0.15) }\end{array}$ & $\begin{array}{c}\text { Small effect } \\
\text { (beta=0.30) }\end{array}$ & $\begin{array}{c}\text { Medium effect } \\
\text { (beta=0.50) }\end{array}$ & $\begin{array}{c}\text { Large effect } \\
\text { (beta=0.70) }\end{array}$ \\
\hline $\begin{array}{l}\text { Country- } \\
\text { year }\end{array}$ & 36 & 0.225 & 0.424 & 0.764 & 0.983 \\
Country & 13 & 0.129 & 0.281 & 0.05 & 0.952 \\
\hline $\begin{array}{l}\text { Country- } \\
\text { year }\end{array}$ & 36 & 0.226 & error $<0.10$ & & \\
& & & 0.581 & 0.960 & 1.000 \\
Country & 13 & 0.351 & 0.720 & & \\
\end{tabular}

Bayesian Credible Interval Analysis (MCMC, uninformative priors, gamma $=0.001)^{\mathrm{a}}$

\begin{tabular}{lcccccc} 
Model & Year & Ineq._growth & $\begin{array}{c}\text { Ineq._ } \\
1980\end{array}$ & Liberal & $\begin{array}{c}\text { Ineq._growth* } \\
\text { Ineq._1980 }\end{array}$ & $\begin{array}{c}\text { Ineq._growth* } \\
\text { Liberal }\end{array}$ \\
\hline M8 & 0.000 & -0.345 & & -0.106 & & \\
& $(0.015)$ & $(1.006)$ & & $(0.119)$ & & \\
M9 & -0.002 & -1.019 & -8.738 & & 11.863 & \\
& $(0.013 "$ & $(1.656)$ & $(2.419)$ & & $(25.956)$ & \\
M10 & -0.006 & -0.489 & & -0.108 & & 1.177 \\
& $(0.016)$ & $(1.001)$ & & $(0.120)$ & & $(1.342)$ \\
M11 & -0.006 & -0.484 & -8.738 & & & 1.178 \\
& $(0.014)$ & $(0.839)$ & $(2.383)$ & & & $(1.124)$ \\
M12 & & -0.718 & -8.730 & & & 0.972 \\
& & $(0.619)$ & $(2.309)$ & & & $(1.030)$ \\
\hline
\end{tabular}

${ }^{\mathrm{a}}$ Following Stegmueller (2013). 
Table A4. Sensitivity test: correlations of fixed-effects model results and institutional context.

\begin{tabular}{llcccc} 
Variable & Definition & $(1)$ & (2) & (3) & (4) \\
\hline (1) Liberal & See Table 2 & 1.000 & & & \\
(2) Inequality_1980 & See Table 2 & -0.005 & 1.000 & & \\
(3) Time Effects & $\begin{array}{l}\text { Random-slope by } \\
\text { country for yearly } \\
\text { counter }\end{array}$ & 0.480 & 0.135 & 1.000 & \\
(4) Inequality_growth Effects & $\begin{array}{l}\text { Random-slope by } \\
\text { country for inequality } \\
\text { change since 1980 }\end{array}$ & 0.418 & 0.064 & 0.947 & 1.000 \\
\hline
\end{tabular}


Figure A1. Within-country income inequality levels and social welfare support by institutional context.

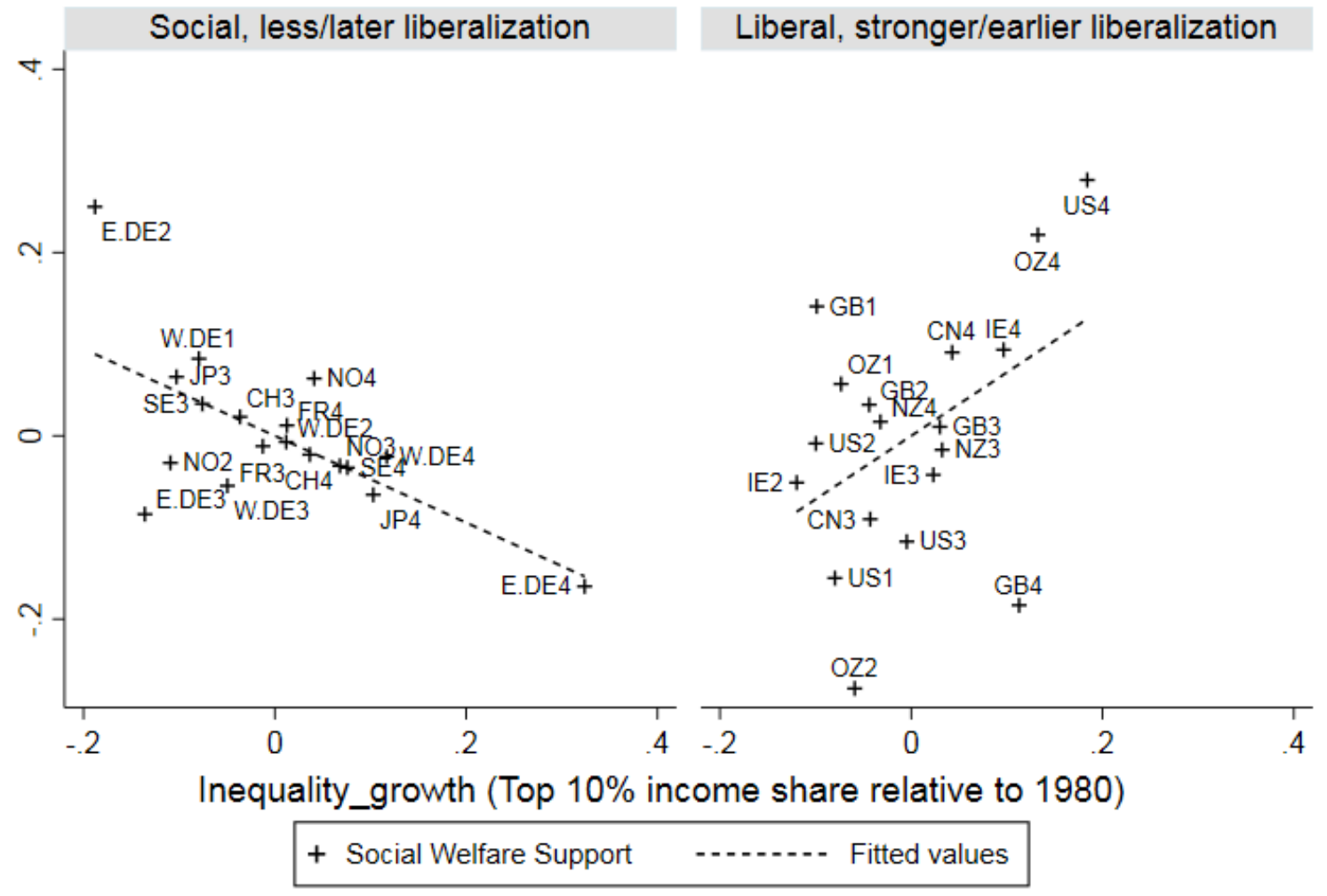

${ }^{\star}$ Mean centered country-time (L2) variance only, time trend adjusted

Note: Results from M11; number after country label indicates wave $(\sim 1986=1 ; \sim 1990=2 ; \sim 1996=3 ; \sim 2006=4)$. 


\section{Addendum}

Question wording from ISSP Role of Government (US Questionnaire).

7. On the whole, do you think it should or should not be the government's responsibility to ...

\section{((PLEASE TICK ONE BOX}

ON EACH LINE))

a. ... provide a job for everyone who wants one

b. ... keep prices under control

c. ... provide health care for the sick

d. ... provide a decent standard of living for the old

e. ... provide industry with the help it needs to grow

f. ... provide a decent standard of living for the unemployed

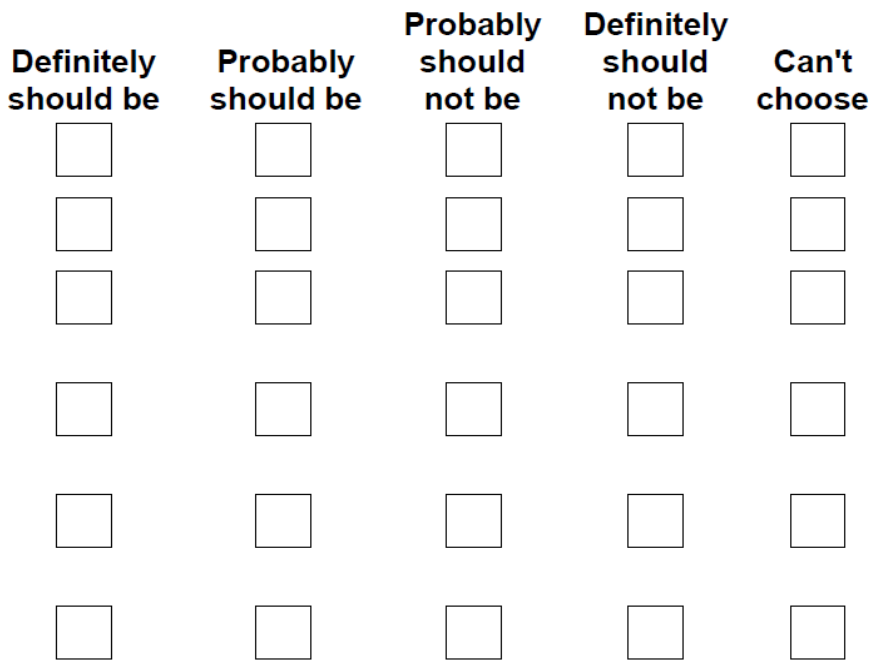

Note: Item-e is not included as we focus on individual welfare, not industrial welfare. 